Ann. Bial. anim. Bioch. Biophys., 1979, 19 (3 A), 583-596.

\title{
Sertoli cell ultrastructure. II. Morphological effects of hypophysectomy in pubescent pigs.
}

par Michelle CHEVALIER

Laboratoire de Biologie cellulaire et génétique

Complexe Scientifique des Cézeaux

B. P. 45,63170 Aubière, France.

Summary. As in normal animals, the Sertoli cell population in pubescent pigs was composed of two morphological cell types : numerous cells with a light nucleus (type A) and some small cells with a dark nucleus (type $B$ ). This report studies the transformations occurring in this population during the 4 months following hypophysectomy. The various cellular components had different rhythms of modification; no general, continuous involution of the components was observed. The nucleolar complex appearing in the nucleus was composed of three elements and persisted during the whole period studied. The majority of A-cell cytoplasmic components disappeared during the post-operative period, except for some lysosomes which developed and the Golgi apparatus which persisted. The cellular junctions between Sertoli cells and those facing the remaining germ cells were unmodified. Three or 4 months after hypophysectomy, the whole of the membranous and ribosomal systems was reorganized and developed. Microtubules and microfilaments gradually disappeared. In some cases the specialized inter-Sertoli cell junctions lost their microfilamentary component. The B-cells had an extremely condensed aspect 1 month after hypophysectomy. Three or 4 months after the operation, cytoplasmic ramifications and the presence of numerous ribosomes apparently indicated a change in B-cell metabolism. The microfilaments disappeared gradually. In both cell types, the large lipid droplet persisted ; it was always found against the nucleus and often in a basal position.

\section{Introduction.}

Murphy $(1965 a, b)$ reported the action of FSH on Sertoli cell morphology. The role of the pituitary has since been confirmed : the Sertoli cell is an FSH target cell (for review, see Steinberger and Steinberger, 1977 ; Means, 1977). The effects of hypophysectomy on Sertoli cells have been studied numerically and structurally by Courot (1970, 1971), Bressler (1976), Aumüller et al. (1978) and Hochereau-de-Reviers and Courot (1978). These same effects have been reviewed from a functional viewpoint by Johnson (1970) and Hagenäs ef al. (1978), who reported on the blood-testis barrier, and by Fritz ef al. (1974), Vernon ef al. (1974), Sanborn et al. (1974, 1975), Weddington et al. (1975), Elkington et al. $(1975,1977)$ and Aumüller ef al. (1978) as concerns the 
production of androgen-binding protein (ABP). Recent work has determined that the Sertoli cells of hypophysectomized rats continue to maintain an efficient blood-testis barrier (Hagenäs et al., 1978) ; these data were obtained with a lanthanum-immersion technique (Neaves, 1973 ; Hagenäs et al., 1977). Testicular ABP production disappeared after hypophysectomy, but was reestablished by FSH administration (Hansson ef al., 1973 ; Fritz et al., 1974 ; Hansson et al., 1974 ; Sanborn ef al., 1974 ; Vernon et al., 1974 ; Sanborn et al., 1975 ; Tindall et al., 1975). This ABP production was maintained or restored in adult hypophysectomized rats given a testosterone treatment (Elkington et al., 1975 ; Aumüller et al., 1978), but when only the androgen was used in prepuberal hypophysectomized animals, the function was not re-established. Therefore, ABP production requires the simultaneous intervention of FSH (Weddington ef al., 1975 ; Elkington et al., 1977).

The present study reports the ultrastructural transformation of pubescent pig Sertoli cells during the interval ( 9 days to 4 months) after hypophysectomy. This operation has a spectacular effect on the testicular structure of pigs (Dufaure et al., 1974 ; Morat, 1977), on pig Leydig cell ultrastructure (Dufaure et al., 1974 ; Chambon et al., 1975 ; Chambon, 1976 ; Morat, 1977) and on that of some accessory glands of the genital tract (Morat ef al., in progress). The effects of hypophysectomy vary from one animal to another, especially during the first weeks following the operation (Morat, 1977).

The Sertoli cell structure of boars has been studied by Fawcett (1975), Osman and Ploën (1978) and Chevalier (1978) ; the Sertoli cell population was found to be bimorphic. Typical A-cells had the same structure as that described in other species. The Bcell cytoplasm was reduced and essentially contained smooth endoplasmic reticulum and many microfilaments. Both cell types had a large lipid droplet (Chevalier, 1978).

\section{Material and methods.}

Seven domestic pigs of the Large-White breed (Sus scrofa L.), weighing about $130 \mathrm{~kg}$, were hypophysectomized at the age of 7 to 8 months. The operation was done at the Station of Reproductive Physiology, INRA (Nouzilly) by A. Locatelli, using the technique of du Mesnil du Buisson ef al. (1964).

Testicular samples were taken on 6 animals 1 month after the operation and on 4 animals 3 and 4 months after hypophysectomy. One additional animal was sampled only 9 days after the operation. Successive samples were taken in regions at a distance from the areas of scarring.

For histological study, pieces of testes were fixed in sublimate Bouin Hollande, embedded in paraffin, cut into $7 \mu \mathrm{m}$ thick sections and stained with glychemalun erythrosine. For cytological study, they were fixed by J. L. Courtens (INRA, Nouzilly) with 2 p. 100 glutaraldehyde in 0.1 M Sorensen's phosphate buffer at $\mathrm{pH} 7.2$ for 20 min., postfixed in 1 p. 100 osmic acid in the same buffer with 4.5 p. 100 sucrose added for $1 \mathrm{hr} .30 \mathrm{~min}$., embedded in epon and cut with a LKB ultramicrotome. The sections were then contrasted with alcoholic uranyl acetate and lead citrate. Observations were made using and $80 \mathrm{KV} \mathrm{JEM} 100 \mathrm{~B}$ electron microscope with direct enlargements of 3000 to 60000 . 
The height of the seminiferous epithelium and the dimensions of Sertoli cell nuclei were determined by histological sections photographed at $\times 400$. Ten measurements per animal were taken of each element. Elongated Sertoli cell nuclei were defined by their extreme diameters ( $D$ and $d)$. The data given correspond to a mean ; they are followed by the standard deviation.

\section{Observations.}

\section{Histological study.}

9 days after hypophysectomy (PI. I, fig. 1). The height of the seminiferous epithelium was $50 \mu \mathrm{m} \pm 5.1$. In 8-month old boars it was $87 \mu \mathrm{m} \pm 6.8$. The cellular content of the tubules was qualitatively unmodified. Sertoli cell nuclei were elongated $(\mathrm{D}=11.8 \mu \pm 0.59 ; \mathrm{d}=7.8 \mu \mathrm{m} \pm 0.84)$. In normal animals, these values were $19.05 \mu \mathrm{m} \pm 0.10$ and $8.47 \mu \mathrm{m} \pm 0.15$, respectively.

1 month after hypophysectomy (PI. I, fig. 2). The height of the seminiferous epithelium was $41 \mu \mathrm{m} \pm 5.2$; it was composed of Sertoli cells, some spermatogonia and degenerating spermatocytes. However, a complete germ stock was found in some boars. The possibility that some residual pituitary activity might persist, will be discussed later. The form of Sertoli cell nuclei was unchanged $(D=11.42 \mu \mathrm{m} \pm 0.22$; $\mathrm{d}=6.51 \mu \mathrm{m} \pm 0.09$ ).

3 and 4 months after hypophysectomy (PI. I, figs. 3 and 4). The aspect of the seminiferous tubules was similar in the different animals. The height of the epithelium of these tubules was about $30 \mu \mathrm{m} \pm 3.07$. It was composed only of Sertoli cells and some rare spermatogonia and spermatocytes which were usually degenerate. The extreme diameters of Sertoli cells were $10.14 \mu \mathrm{m} \pm 0.20$ (D) and $5.80 \mu \mathrm{m} \pm 0.09$ (d). The tubule lumen was reduced or even blocked. The sex cells were eliminated and the seminiferous tubules contracted, thus decreasing tubule diameter and Sertoli cell occupation of all the tubule epithelium. No Sertoli cell mitosis was observed.

\section{Ultrastructural study.}

9 days after hypophysectomy there were no changes in the distribution of the two morphological cell types described in normal animals. Cellular structures were very similar to those seen before the operation. Junctions between adjacent Sertoli cells and those associating Sertoli cells to germ cells were unmodified in the animal studied.

1 month after hypophysectomy the Sertoli cell population was polymorphic. Some of these cells showed necrosis, although the nucleus retained several normal Sertoli cell characteristics, i. e. very irregular shape, clear nucleoplasm containing no compact chromatin. The microfilaments, microtubules, endoplasmic reticulum (ER) and most of the ribosomes had disappeared from the cytoplasm ; the Golgi apparatus and some mitochondria were intact. Numerous vesicles bounded by a single or double membrane were also seen in the cytoplasm. The last vesicles represented degenerating mitochondria. Large lysosomes were particularly numerous. The plasmic membrane was often discontinuous. 


\section{PLATE I}

FIGS. 1-4. - Effect of hypophysectomy on boar seminiferous epithelium.

FIG. 1, - 9 days after hypophysectomy. The germ stock is still complete. Note the Leydig cells already atrophied, between 2 seminiferous tubules $(\times 440)$.

FIG. 2. -1 month after hypophysectomy. Germ cells are scarce $(\times 1100)$.

FIG. 3. -3 months after hypophysectomy ( $\times 1100$ ).

FIG. 4. -4 months after hypophysectomy $(\times 1100)$.

FIG. 5. - Ultrastructure of the nucleus and the perinuclear region of a Sertoli B-cell 1 month after hypophysectomy.

Note very dense cytoplasm, the irregularly-shaped nucleus and its parallel orientation to the basement membrane ( $\times 13$ 000) (BL : basement membrane ; $L$ : lipid ; LC : Leydig cells ; Nu : nucleolus ; $S$ : Sertoli cell ; Spc : spermatocyłes ; Spd : spermatids). 


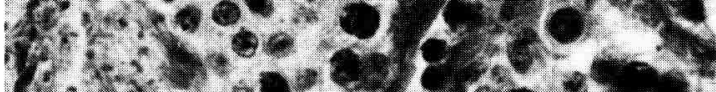

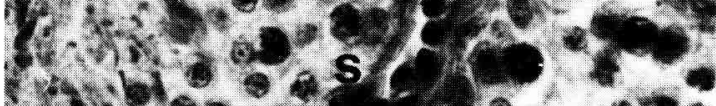

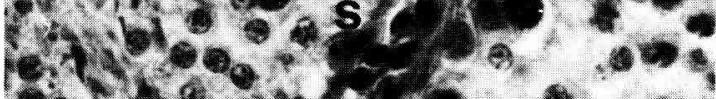
0 r o. - -5.050 In lo 20. orut 4321
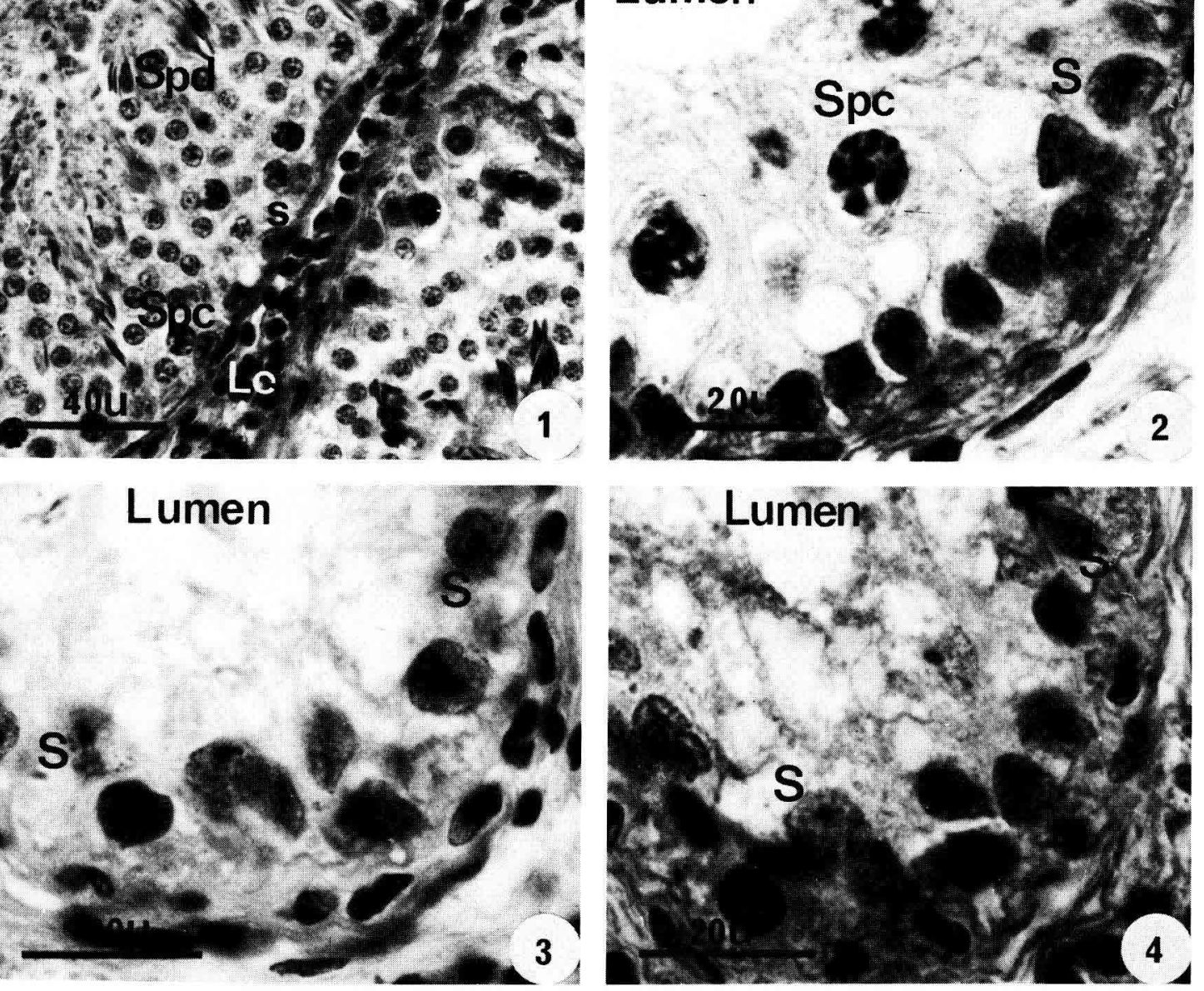

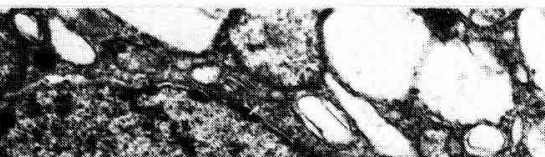

T.

$\mathrm{Nu}$

\section{$x+2 y$}

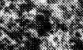

\section{- $x$}

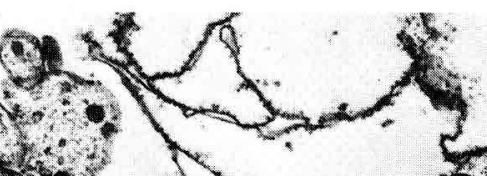

$30^{\circ}=3$ ?

eqenerating cells 
The Sertoli cells which appeared normal could be classed into two unequal groups: numerous cells with a light nucleus (PI. II, fig. 1) and some cells with a very dark nucleus (PI. I, fig. 5). By analogy with normal animals (Chevalier, 1978), they have been called A-cells and B-cells, respectively.

The A-cells (PI. II, fig. 1) were large and had a wavy outline; they contained the same elements as the typical Sertoli cells of normal pubescent animals, but more scattered. Several pecularities were observed.

The deeply-indented nucleus often enclosed a complex composed of a central nucleolus flanked by two round masses of compact chromatin (PI. II, fig. 2). The fibrillar and granular components of the nucleolus overlapped closely. A patch of interchromatin granules was often observed near the nucleolus.

Hypophysectomy caused a considerable decrease in the number of cytoplasmic microtubules, microfilaments and free ribosomes, while large lysosomes were numerous. The infer-Sertoli cell junctions were retained ; desmosome-type junctions, associating Sertoli cells with germ cells, persisted. Some hemi-junctions, facing spermatocytes, remained.

The B-cells (PI. I, fig. 5), smaller and more regular, had a very dense aspect. Their deeply-indented nucleus was elongated parallel to the basement membrane and contained many small masses of compact chromatin. The nucleolus might form a complex identical to that described above. The cytoplasm contained very vesicular smooth ER, ribosomes, small mitochondria with lamellar cristae, some dictyosomes and lysosomes and a large lipid droplet. No specialized inter-Sertoli cell junction was observed.

3 and 4 months after hypophysectomy the Sertoli cell population was still composed of two morphological cell types : A-cells (PI. III, fig. 1) and B-cells. The A-cells (PI. III, fig. 1) had an indented nucleus including a quantity of compact chromatin which varied from one cell to another. Nucleolar structure was usually that described above (PI. III, fig. 1).

The cytoplasm was reorganized, showing a very clear development of its membranous and ribosomal systems; the ribosomes were abundant and often grouped

PLATE II

Ulirastructure of a Sertoli A-cell 1 month after hypophysectomy.

(BL : basement membrane; $G$ : Golgi apparatus ; Ly : lysosome ; Nu : nucleolus ; $\mathrm{S}$ : Sertoli cell)

FIG. 1. - Overall aspect. Note the orientation of the cell at a right angle to the basement membrane $(x 13000)$.

FIG. 2. - Part of a nucleolar complex. Note round mass of compact chromatin beside the nucleolus (asterisk). ( $\times 15000)$. 


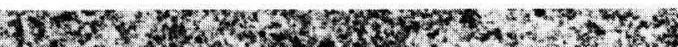

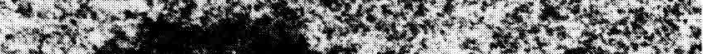

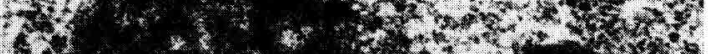

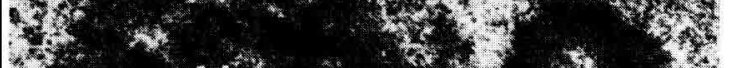

8. 4. Nu $\cos ^{2}$

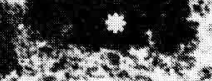

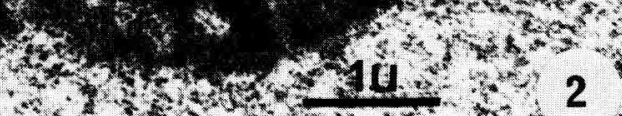

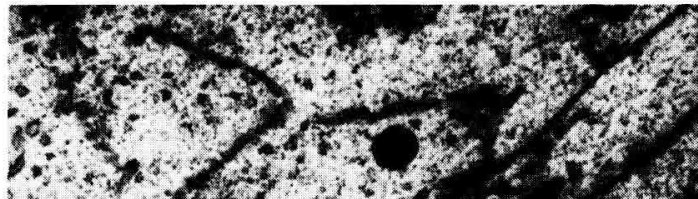

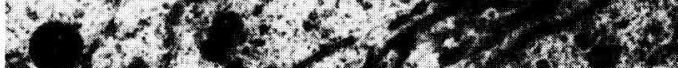
Explat? 2

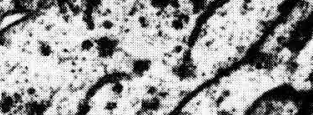

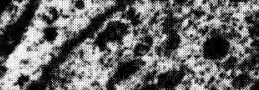

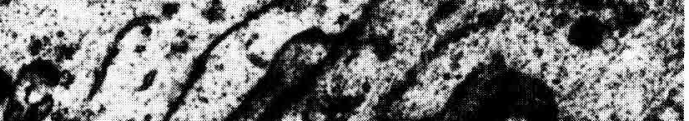

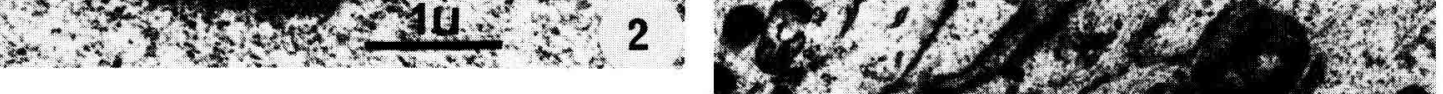

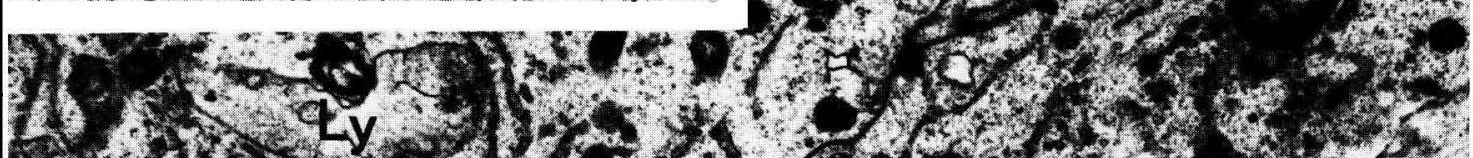

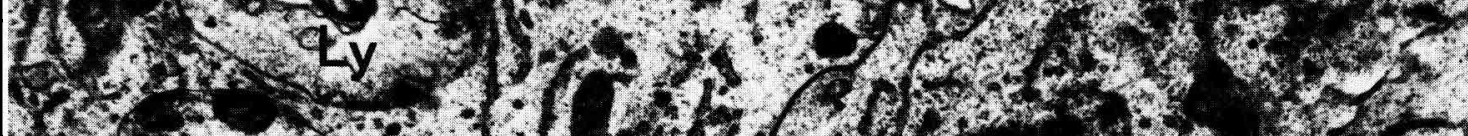

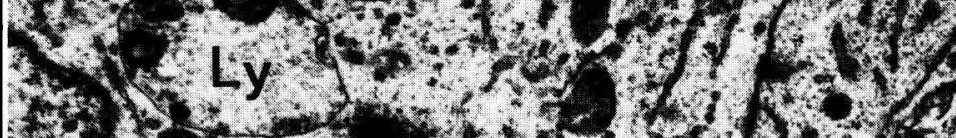

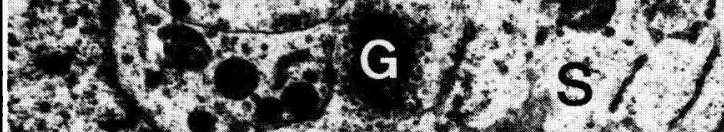

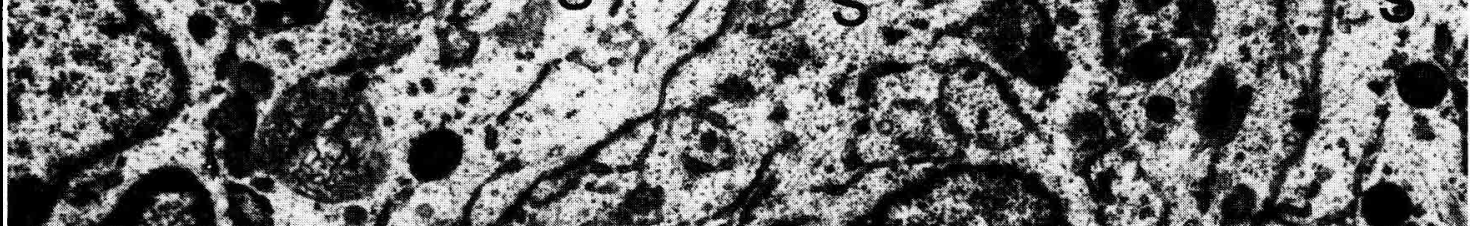

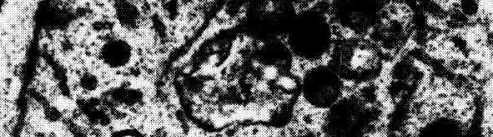

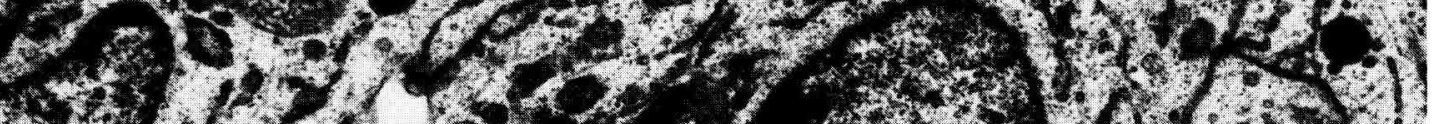

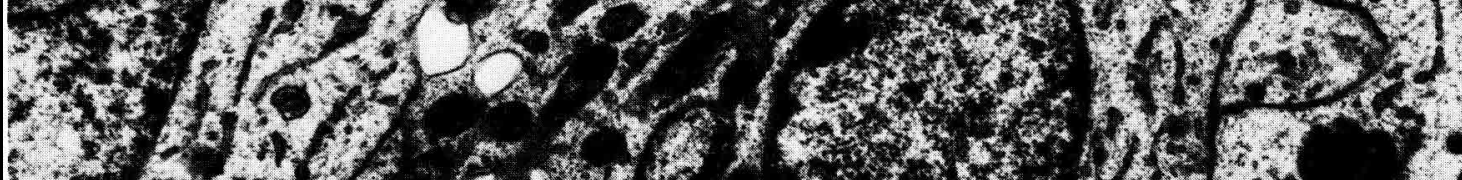

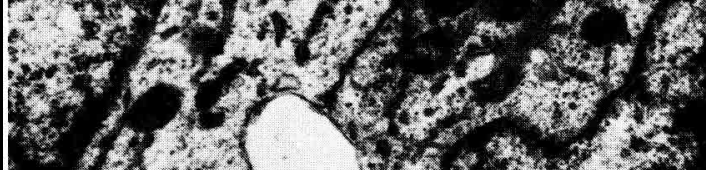

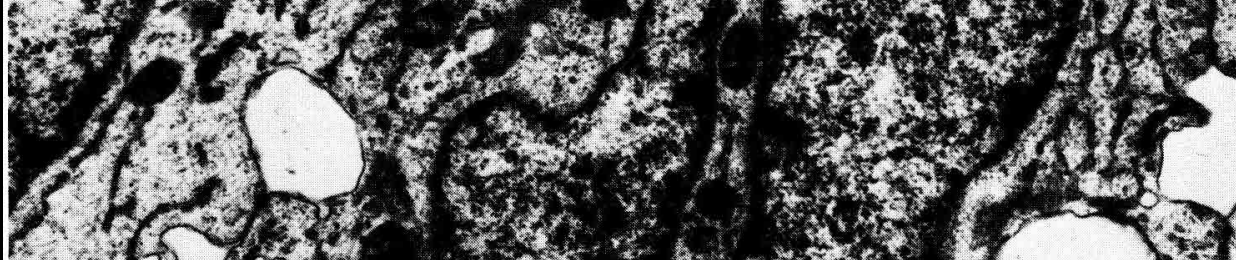
Sf

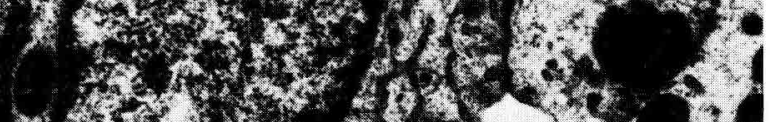

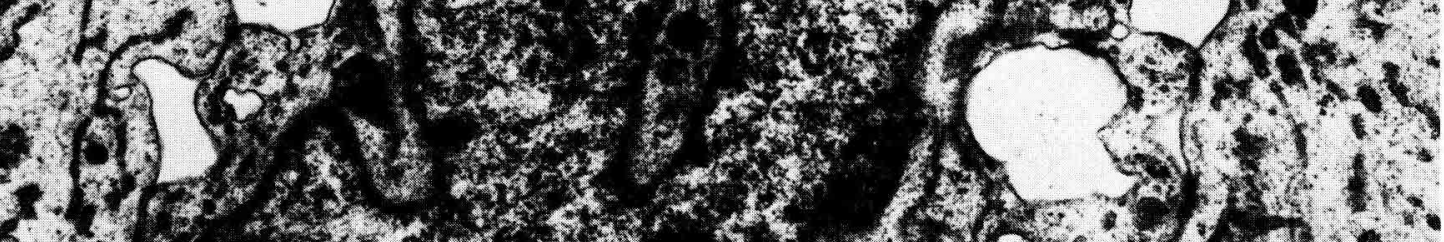
F.

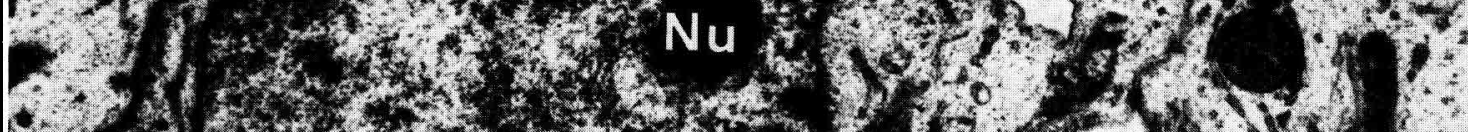

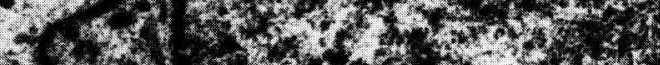

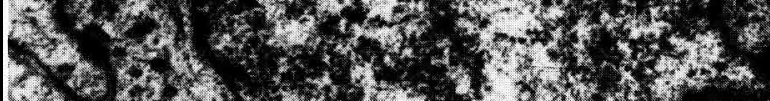

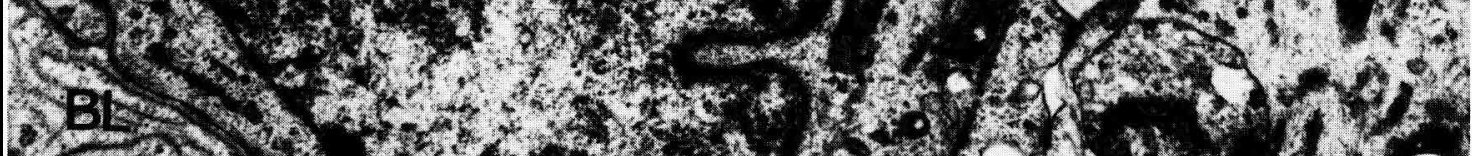

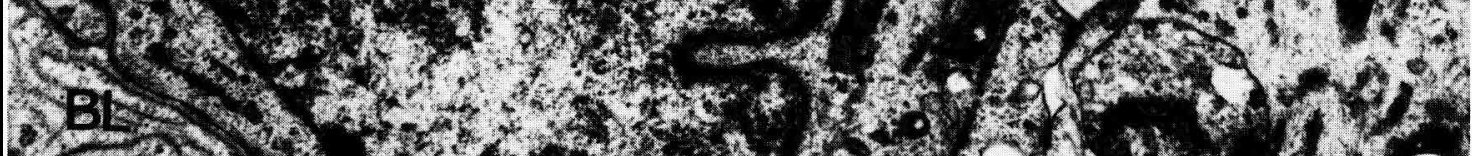

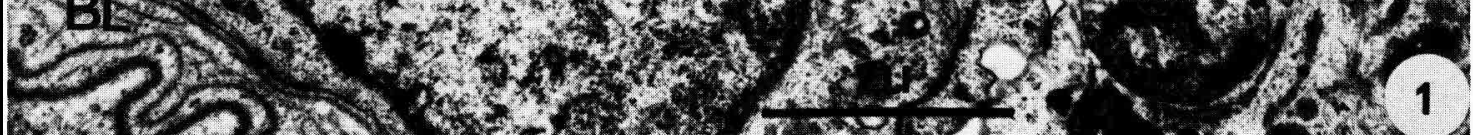

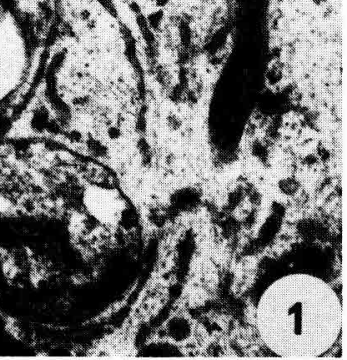


into polysomes. The Golgi apparatus was formed of many dictyosomes surrounded by coated vesicles (PI. III, fig. 3). The mitochondria were elongated into a dumb-bell shape or sometimes into a ring-shape (PI. III, fig. 1) ; their matrix was dense and their cristae lamellar and transversal. In some cells, the figures suggested mitochondrial degeneration. Smooth ER was abundant and usually found in the form of dilated saccules (PI. III, fig. 1), but might also be observed as large concentric circles identical to those described in normal animals (PI. III, fig. 2). Some dark vesicles about $70 \mathrm{~nm}$ in diameter, located on the periphery of a circle, were observed (PI. III, fig. 3), as described in other physiological conditions (immaturity, puberty, cryptorchidy). There were fewer lysosomes than previously. Microtubules were absent in many sections, but could be seen in others, thus indicating a very unequal distribution of that component. Microfilaments outside the perinuclear region had disappeared. Some Charcot-Bötcher's crystalloids remained ; these were poorly developed and rarely surrounded by smooth ER. A large lipid droplet was situated between the nucleus and the basement membrane (PI. III, fig. 1).

Inter-Sertoli cell junctions were generally unmodified (PI. III, figs. 4, 6). However, in some cases the microfilaments in the specialized junctions had disappeared (PI. III, fig. 5). When sex cells persisted, some hemi-junctions, facing the spermatocytes, were still present.

The B-cells occupied the same position as previously described, but they were more branched and less dense. Their deeply indented nucleus was elongated parallel to the basement membrane. The nucleoplasm enclosed many small masses of compact chromatin. The cytoplasm contained lysosomes, smooth ER and many ribosomes and dumb-bell-shaped mitochondria ; there were fewer microfilaments. No inter-Sertoli cell junction was observed.

Ultrastructure of a Serfoli A-cell 3 and 4 months after hypophysectomy.

(BL : basement membrane ; ER : smooth endoplasmic reticulum ; $G$ : Golgi apparatus ; $\mathrm{L}$ : lipid ; $N$ : nucleus ; Nu : nucleolus ; $S$ : Sertoli cell ; SSC : sub-surface cisternae)

FIG. 1. - Overall aspect. Note the nucleolar complex and the lipid droplef located under the nucleus $(\times 11200)$.

FIG. 2. - Elongated saccules of smooth ER arranged in large concentric circles ( $\times 10500)$.

FIG. 3. - Group of dark vesicles near a dictyosome $(\times 32000)$.

FIG. 4. - Specialized inter-Sertoli cell junction having the structure of normal animals ( $\times 30000)$.

FIG. 5. - Specialized inter-Sertoli cell junction with its microfilamentary component missing $(\times 30000)$.

FIG. 6. - Inter-Sertoli cell junctions in the basal region of the cell. Note smooth ER (X30000). 


\section{Discussion.}

The Sertoli cell population in hypophysectomized boars was composed of two cell types. This dual morphology has already been reported in prepuberal pigs by Wrobel and Dierichs (1975) and described by Chevalier (1978) in pubescent and cryptorchid pigs as well as in humans by Johnsen (1969) and Wartenberg (1978). Two cell types in rats have also been reported in in vitro culture by de Marfino et al. (1977).

From an ultrastructural viewpoint, hypophysectomy causes no general, continuous involution of the whole of the cellular composents, as is the case of the Leydig cells in the same conditions (Chambon ef al., 1975 ; Chambon, 1976 ; Morat, 1977). After hypophysectomy, Sertoli cell nuclei decreased in size and exhibited a more spherical shape ; these observations correspond to those of Dym and Madhwa Raj (1978) in rats treated with an anti-LH serum. Moreover, a central nucleolar complex, flanked by two round satellites, formed in the nucleus. That the satellites are of a chromatin nature has been shown in rats (for review, see Fawcett, 1975). This nucleolar complex is found in pigs (Chevalier, 1978), but it was not considered as a characteristic element in Large-White adults (Chevalier, 1978), while it has been reported as such in the Swedish Landrace (Osman and Ploën, 1978). This nucleolar complex has also been described in some adult rodents (Sapsford, 1963 ; Flickinger, 1967 ; Fawcett, 1975 ; Krimer, 1977). Its formation in rats and mice (Bressler, 1976) has been considered as an element distinguishing Sertoli cell maturation. For Krimer (1977), the presence of a large complex and the nucleolar structure itself indicated a high cellular activity according to the concepts of Bernhard (1971). The frequency of this formation in hypophysectomized pigs appears to be in disagreement with the preceding hypothesis. On the contrary, the two juxtanucleolar masses might be considered as a result of chromatin condensation, corresponding to a pause in the Sertoli cell functions controlled by FSH. However, it might also be that the considerable phagocytic activity, which immediately follows hypophysectomy, and the cellular reorganization observed 3 months after the operation indicate the reorientation of cellular function, expressed in the juxtanucleolar chromatin. Morphological observation alone does not permit a definitive conclusion.

The transformation in the cytoplasm follows different rhythms, depending on the component. At first, A and B-cells react differently. The considerable lysosomal development in A-cells indicates intense phagocytic activity, eliminating some degenerate sex cells and causing limited autolysis of the cell. This would reduce the number of organelles such as ER, mitochondria and ribosomes.

B-cells, on the contrary, are very dense as a result of considerable cytoplasmic contraction. According to the quantity of lysosomes present, their phagocytic activity is lower than that of A-cells. The Golgi apparatus of B-cells, as in A-cells, is little affected.

Three months after hypophysectomy, a very evident cytoplasmic reorganization was observed in all cases. This was expressed by the restoration of such organelles as smooth ER, mitochondria and ribosomes which had disappeared in the postoperative period. The number of microfilaments and microtubules continually decreased in both cell types. 
From these observations, the cytoplasmic components may be divided into several groups according to their responsiveness to the operation : the ER, ribosomes and mitochondria (whose density decreases then increases again) and the fibrillar formations which gradually disappear. These differences might give an indication of the mechanisms of pituitary hormone control of the Sertoli cells. However, this question is complicated due to the fact that the effects may be direct (depletion of FSH or another pituitary hormone) or indirect (disappearance of sex cells, testosterone depletion).

The synthesis of microfilaments and microtubules is surely under pituitary control ; hey decreased continuously during the period studied. Their disappearance is not consecutive to that of the germ cells since in cryptorchid pigs (Toyama, 1975 ; Chevalier, 1978), these formations are particularly abundant, although the spermatogenetic stock is usually entirely absent. The microfilaments must be studied in relation to the blood-testis barrier. Some authors believe that this barrier is not completely pituitarydependent (Vitale et al., 1973), and in some studies on rats hypophysectomy did not cause a rupture of the barrier (Johnson, 1970 ; Hagenäs et al., 1978 ; Aumüller ef al., 1978). However, the microfilamentary component of specialized junctions begins to disappear in pigs 3 months after the operation. This is probably due to the fact that normal pubescent animals have a large quantity of microfilaments with a slow turnover. If would be interesting to know if, after this time interval, the barrier is stil as efficient.

The situation as concerns the ER, ribosomes and mitochondria is less clear. The late reorganization of these organelles might mean that their evolution is not entirely under pituitary control. However it could be that some cells producing pituitary hormones reappear after a certain time. In relation to this hypothesis, it should be noted that (i) the hypophysectomy, was always extensive and included the pituitary stalk (A. Locatelli, personal communication), (ii) the observations on different animals are in complete agreement, (iii) studies of Leydig cells in the same animals show no resumption of LH activity (Morat, 1977). The depletion of the number of organelles previously mentioned must be a result of intense phagocytosis directed towards the degenerating sex cells. Heterophagic activity would also cause some autophagy. Then, when lysosomal activity decreased after the germ cells were eliminated, those cytoplasmic components would reconstitute themselves.

In conclusion, the diversity of Sertoli cell transformations after hypophysectomy indicates that the various functions of these cells are controlled by some complex mechanisms.

Reçu en sepiembre 1978.

Accepté en novembre 1978.

Résumé. Chez le porc pubère hypophysectomisé, comme chez l'animal normal, la population sertolienne est composée de deux types morphologiques de cellules: de nombreuses cellules à noyau clair (type $A$ ) et quelques petites cellules à noyau sombre (type B).

La population sertolienne subit des transformations qui ont été étudiées au cours des 4 mois qui suivent l'opération. Le rythme des modifications est différent suivant les constituants cellulaires. Il n'y a pas d'involution générale et continue de l'ensemble de ces derniers. 
Dans le noyau, il apparaît un complexe nucléolaire à structure tripartite. Ce phénomène se poursuit tout au long de la période éłudiée.

Le cytoplasme des cellules A au cours de la période qui suif l'opération se vide de la majorité de ses composants à l'exception des lysosomes qui se développent et de l'appareil de Golgi qui persiste. Les jonctions cellulaires demeurent inchangées entre les cellules de Sertoli et face aux cellules germinales restées en place. Trois ou 4 mois après l'hypophysectomie, il y a une réorganisation et un développement de l'ensemble des systèmes membranaires et des ribosomes. Les microtubules ef les microfilaments disparaissent progressivement. Les jonctions intersertoliennes spécialisées ont perdu, dans certains cas, leur composante microfilamentaire.

Les cellules $B$ ont un aspect extrêmement condensé un mois après l'hypophysectomie. Trois ou 4 mois après l'intervention, l'apparition de ramifications cytoplasmiques et la présence de nombreux ribosomes semblent indiquer un changement dans lemétabolisme de cette cellule. Les microfilaments disparaissent progressivement.

Dans les 2 types cellulaires, le volumineux globule lipidique persiste ; il est dans tous les cas situé contre le noyau et souvent en position basale.

\section{References}

AUMÜLLER G., SCHILLER A., SCHENCK B., VON BERSWORDT-WALLADE R., 1978. Fine structure of Sertoli cells in the rat testis after hypophysectomy, testosterone treatment and re-involution. Cytobiologie, 17, 453-463.

BERNHARD W., 1971. Drug induced changes in the interphase nucleus, 49-62. In CLEMENTI F., CECCARELLI B. Advances in cyfopharmacology. Vol. 1 : Ist int. Symp. cell. Biol. and Cytopharmacol., Raven Press, New York.

BRESSLER R. S., 1976. Dependence of Sertoli cell maturation on the pifuitary gland in the mouse. Am. J. Anat., 147, 447-456.

CHAMBON M., 1976. Action en culture organotypique de l'hormone chorionique gonadotrope (HCG) sur l'ultrostructure des cellules de Leydig du testicule de verrat hypophysectomisé. Thèse Doct. $3^{\mathrm{e}}$ cycle, Clermont-Ferrand, $74 \mathrm{pp}$.

CHAMBON M., MORAT M., CHEVALIER M., DUFAURE J. P., 1975. Réorganisation mitochondriale consécutive à la stimulation par HCG des cellules de Leydig du testicule de porc hypophysectomisé. C. R. Acad. Sci. Paris, Série D, 281, 1011-1014.

CHEVALIER M., 1978. Sertoli cell ultrastructure. I. - A comparative study in immature, pubescent, adult and cryptorchid pigs. Ann. Biol, anim. Bioch. Biophys., 18, 1279-1292.

COUROT M., 1970. Effect of gonadotropins on the seminiferous tubules of the immature testis, 355-367. In ROSEMBERG E., PAULSEN C. A., The human testis. Plenum Press, New York.

COUROT M., 1971. Etablissement de la spermatogenèse chez l'agneau (Ovis aries). Efude expérimentale de son contrôle gonadotrope; importance des cellules de la lignée sertolienne. Thèse Doct. Sci. nat., Univ. Paris VI, A. O. 6317. Cent. Doc. C.N.R.S. 200 pp.

DUfAURE J. P., du MESNIL du BUISSON F., MORAT M., CHEVALIER M., LOCATELLI A., 1974. Effets de l'hypophysectomie ef de l'administration d'hormone gonadotrope (HCG) sur les cellules de Leydig du testicule de verrat. C. R. Acad. Sci. Paris, Série D, 279, 1907-1910.

Du MESNIL du BUISSON F., LEGLISE P. C., CHODKIEWICZ J. P., 1964. Technique de l'hypophysectomie par voie transfrontale sus-orbitaire chez le porc. Ann. Biol. anim. Biochim. Biophys., 4, $229-237$.

DYM M., MADHWA RAJ H. G., 1977. Response of adult rat Sertoli cells and Leydig cells to depletion of luteinizing hormone and testosterone. Biol. Reprod., 17, 676-696.

ELKINGTON J. S. H., SANBORN B. M., STEINBERGER E., 1975. The effect of testosterone propionate on the concentration of testicular and epididymal androgen binding activity in the hypophysectomized rat. Molec. cell. Endocrinol., 2, 157-170.

ELKINGTON J. S. H., SANBORN B. M., MARTIN N. W., CHOWDHURY A. K., STEINBERGER E., 1977. Effect of festosterone propionate on ABP in rats hypophysectomized at different ages using individual sampling. Molec. cell. Endocrinol., 6, 203-219. 
FAWCETT D. W., 1975. Ultrastructure and function of the Sertoli cell, 21-25. In GREEP R. O., ASTWOOD C. B., Handbook of Physiology, sect. 7, Endocrinology, Vol. 5, Male reproductive system. Physiol. Soc., Washington D. C.

FLICKINGER C. J., 1967. The postnatal development of the Sertoli cells of the mouse. Z. Zellforsch., 78, 92-113.

FRITZ I. B., KOPEC B., LAM K., VERNON R. G., 1974. Effects of FSH on levels of androgen binding protein in the testis, 311-327. In DUFAU M., MEANS A., Hormone binding and targef cell activation of the testis, Vol. 1. Plenum Press, New York.

HAGENÄS L., PLOËN L., RITZEN E. M., EKWALL H., 1977. Blood-testis barrier : Maintained function of inter-Sertoli cell junctions in experimental cryptorchidism in the rat, as judged by a simple lanthanum-immersion technique. Andrologia, 9, 250-254.

HAGENÄS L., PLOËN L., EKWALL H., 1978. Blood-testis barrier : evidence for intact inter-Sertoli cell junctions after hypophysectomy in the adult rat. J. Endocrinol., 76, 87-91.

HANSSON V., REUSCH E., TRYGSTAD O., TORGERSEN O., FRENCH F. S., RITZEN E. M., 1973. FSH stimulation of testicular androgen binding protein (ABP) Noture (New Biol.), 246, 56-59.

HANSSON V., FRENCH F. S., WEDDINGTON S. C., NAYFEH S. N., RITZEN E. M., 1974. FSH stimulation of testicular androgen binding protein, 287-290. In DUFAU M. L., MEANS A. R., Hormone binding and torget cell activation in the testis. Plenum Press, New York.

HOCHEREAU-de REVIERS M. T., COUROT M., 1978. Sertoli cells and development of seminiferous epithelium. Ann. Biol. anim. Bioch. Biophys., 18, 573-583.

JOHNSEN S. G., 1969. Two types of Sertoli cells in man. Acto endocr., 61, 111-116.

JOHNSON M. H., 1970. The pituitary and the blood testis barrier. J. Reprod. Fertil., 22, 181-186.

KRIMER D. B., 1977. Ultrastructural and cytochemical aspects of the nucleus of mouse Sertoli cells. Arch. Biol. 88, 117-126.

MARTINO C. de, MARCANTE M. L., FLORIDI A., CITRO G., BELLOCCI M., CANTAFORA A., NATALI P. G., 1977. Sertoli cells of adult rats in vitro. A morphologic and functional study. Cell Tiss. Res., 176, 69-90.

MEANS A. R., 1977. Mechanisms of action of follicle stimulating hormone (FSH), 163-198. In JOHNSON A. D., GOMES W. R., The testis. Vol. 4. Acad. Press, New York.

MORAT M., 1977. Action morphogène des hormones gonadotropes sur les cellules de Leydig du testicule du verrat. I. - Effets de l'hypophysectomie. Arch. Anat. microsc., 66, 119-142.

MURPHY H. D., 1965a. Sertoli cell stimulation following intratesticular injections of FSH in the hypophysectomized rat. Proc. Soc. exp. Biol. Med. (N. Y.), 118, 1202-1205.

MURPHY H. D., 1965b. Intratesticular assay of follicle-stimulating hormone in hypophysectomized rats. Proc. Soc. exp. Biol. Med. (N. Y.), 120, 671-675.

NEAVES W. B., 1973. Permeability of Sertoli cell tight junctions to lanthanum after ligation of ductus deferens and ductuli efferents. J. Cell Biol., 59, 559-572.

OSMAN D. I., PLOËN L., 1978. The ultrastructure of Sertoli cells in the boar. Int. J. Andrology, 1, 162-179.

SANBORN B. M., ELKINGTON J. S. H., STEINBERGER E., 1974. Properties of rat testicular androgen binding proteins, 291-310. In DUFAU M. L., MEANS A. R., Hormone binding and target cell activation in the testis. Plenum Press, New York.

SANBORN B. M., ELKINGTON J. S. H., CHOWDHURY M., TCHOLAKIAN B. K., STEINBERGER E., 1975. Hormonal influences on the level of testicular androgen binding activity : effect of FSH following hypophysectomy. Endocrinology, 96, 304-312.

SAPSFORD C. S., 1963. The development of the Sertoli cell of the rat and mouse : its existence as a mononucleate unit. J. Anat., 97, 225-238.

STENBERGER A., STEINBERGER E., 1977. The Sertoli cells, 371-399. In JOHNSON A. D., GOMES W. R., The testis, Vol. 4. Acad. Press, New York.

TINDALL D. J., SCHRADER W. T., MEANS A. R., 1975. The production of androgen binding protein by Sertoli cells, 167-175. In DUFAU M. L., MEANS A. R., Hormone binding and target cell activation in the testis. Plenum Press, New York.

TOYAMA Y., 1975. Ultrastructural study of crystalloids in Sertoli cells of the normal, intersex and experimental cryptorchid swine. Cell Tiss. Res., 158, 205-213.

VERNON R. G., KOPEC B., FRITZ I. B., 1974. Observations on the binding of androgens by rat testis seminiferous tubules and testis extracts. Mol. cell. Endocrinol., 1, 167-187. 
VITALE R., FAWCETT D. W., DYM M., 1973. The normal development of the blood-testis barrier and the effects of clomiphene and estrogen treatment. Anat. Rec., 176, 333-344.

WARTENBERG H., 1978. Human testicular development and the role of the mesonephros in the origin of a dual Sertoli cell system. Andrologia, 10, 1-21.

WEDDINGTON S. C., HANSSON V., RITZEN E. M., HAGENAS L., FRENCH F. S., NAYFEH S. N., 1975. Sertoli cell secretory function after hypophysectomy. Nature, 254, 145-146.

WROBEL K. H., DIERICHS R., 1975. Wachstum und Differenzierung der Sertolizellen im Schweinehoden während der postnatalen Ontogenese. Verh. Anat. Ges., 69, 723-724. 